\section{India makes waves over tsunami warning system}

\section{HYDERABAD}

India has agreed to share seismic data from four of its monitoring stations as part of a tsunami warning system for the Indian Ocean. But its offer has left many unimpressed.

The warning system will use a maze of deep ocean sensors and tide gauges surrounding the fault that ruptured on 26 December 2004. This earthquake triggered a tsunami that killed more than 200,000 people in 11 countries. But crucial to the network will be real-time seismic data from stations in the region.

India has been averse to sharing its seismic data in order to keep information about its underground nuclear tests a secret. ${ }^{\alpha}$ The only station that is available to the global seismic network has a delay of about three weeks before data are disseminated, says Walter Mooney of the US Geological Survey, headquartered in Reston, Virginia.

India's offer, announced at the second meeting of the Intergovernmental Coordination Group (ICG) in Hyderabad last week, is limited to data on earthquakes with a magnitude of six and above, along the coast of Indonesia and Pakistan. Signals from nuclear tests would be much weaker than this. "For the purpose of tsunami warning we think our offer should be quite satisfactory," India's science secretary Valangiman Ramamurthy told Nature.

Not everyone agrees, because of the time it would presumably take to filter the data. ${ }^{\alpha} \mathrm{A}$ delay of even a minute in the dissemination of earthquake information could increase casualties," says a report by an ICG working group released at the meeting. ${ }^{\alpha} \mathrm{We}$ were pinning our hopes on real-time seismic signals from India," adds Reinhold Ollig, head of a delegation from Germany that is helping Indonesia to build a national tsunamiwarning centre in Jakarta. "Now we may have to upgrade a station in Sri Lanka for a realtimelink."

The Indian offer, even though it is limited, is “a sign of progress", Patricio Bernal, executive secretary of the United Nations' Intergovernmental Oceanographic Commission, told Nature. He says Indian Ocean countries
IMAGE

UNAVAILABLE FOR COPYRIGHT REASONS

A tsunami early-warning network for the Indian Ocean should be in place by 2009.

should be in a position to confirm the advance existence of a tsunami by September 2006, and that the fully fledged warning system is on track for completion by the end of 2008 .

But as the first anniversary of the Asian

\title{
Diet book attacked for its high-protein advice
}

\section{SYDNEY}

A diet book developed by researchers at Australia's largest government laboratory network has already made the organization more than A \$1.5 million (US\$1.1 million) in royalties. But its success is feeding a growing body of critics who say that its high-protein message is not supported by the evidence. They also question the influence of the meat industry, which sponsored it.

"It's far more successful than we ever anticipated," says Manny Noakes of the Commonwealth Scientific and Industrial Research Organization (CSIRO) in Adelaide, who wrote The CSIRO Total Wellbeing Diet with her colleague Peter Clifton.

The book has become a national bestseller, having sold nearly half a million copies since its launch in May. It went on sale in Britain in September, with release in further countries, induding the United States, planned for 2006. Its recommendations even feature on

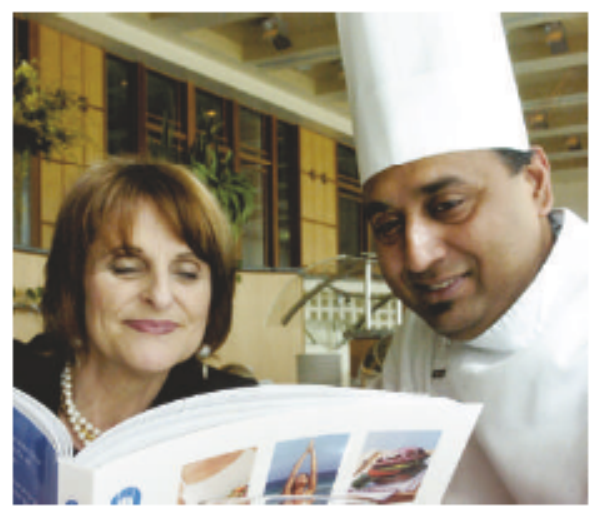

Manny Noakes (left) co-authored a book that advocates eating more protein for weight loss.

the menu at Australia's Parliament House.

But critics have spoken out about the possible influence of the Australian meat and livestockindustry, which funded a large portion of the research behind the high- protein diet. "There is a bias towards the sponsor's product which is not justified by the results of their research," says Rosemary Stanton, a nutritionist and visiting fellow at the University of New South Wales in Sydney.

The diet advocates a much higher protein intake than that recommended by most national guidelines. People on a typical Western diet obtain about $15 \%$ of their energy intake as protein, but the CSIRO diet recommends doubling that to $30-35 \%$ while reducing carbohydrate intake. To achieve this, Noakes and Clifton suggest eating more meat and fish at lunch and dinner.

"You have to ask why they didn't promote more plant-based proteins," says Stanton. "Did their choice of protein come about because of the sponsor?" The authors insist that the industrial sponsors were kept at arm's length. “They didn't have any impact on the design of the study and how we interpreted the results," says Clifton. 


\section{IMAGE \\ UNAVAILABLE FOR COPYRIGHT REASONS}

tsunami approaches, there is concern at the news that the ICG has dropped the idea of one or two countries being responsible for issuing a warning across the region through the network. The ICG was worried that the proposal had "overly controlling connotations", despite a similar system being in use at the Pacific Tsunami Warning Center in Hawaii. Instead, the ICG suggests that the Intergovernmental Oceanographic Commission should accredit certain nations as 'watch providers' from whom, under bilateral agreements, other nations could obtain details of any events detected. It would then be up to individual nations to decide whether to issue a warning within their own territory. Indonesia, India, Thailand, Malaysia and Australia plan to have their national warning centres in operation before 2009.

Individual nations will be able to enter into bilateral arrangements with as many watch providers as they wish, which means that there will not be a single alert but several voices, depending on how many providers each nation ties up with. ${ }^{\alpha}$ There is going to be chaos," warns K. Radhakrishnan, former director of the Indian National Centre for Ocean Information Services in Hyderabad.

Here, too, India is choosing its own path. It is investing US $\$ 30$ million to upgrade its 70 seismic stations, deploying ten deep underwater pressure sensors and installing 50 satellitelinked tide gauges. It plans to have its warning centre running by September 2007 but says it will not subject itself to the ICG s accreditation process. "What India is doing is adequate for the entire Indian Ocean region," says Ramamurthy. "If any country wants to work with us in tandem we have no problem.

K.S. Jayaraman
ON THE RECORD

"Ihate being cold."

British swimmer Lewis Pugh has some qualms about attempting a record 1-kilometre swim in thefrigid waters of the Southern Ocean.

“On a deeper level Barbie has become inanimate... This may go some way towards explaining the violence and torture."

Psychologist Agnes Naim expla ins how young girls apparentlysee the ubiquitous plastic doll as a symbol of excess, triggering them to decapitate and maim their Barbies.

Sources: Reuters, The Times

\section{SCORECARD}

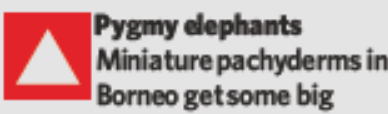
attention, in the form of global positioning system collars that track their every move through the rainforest.

\section{Sounds without words An obscure buzzing sound present in some} 70 African languages, and known as the labiodental flap, joins the International Phonetic Alphabet - the first suchaddition in a dozenyears.

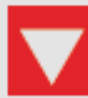
Army hygiene Studies of body lice and dental pulp from French

"I think it is dangerous long-term," he says. The authors based the diet on several studies, the largest being their own trial of 100 overweight women over 12 weeks (M. Noakes et al. Am. J. Clin. Nutr. 81, 1298-1306; 2005). Half the women were given a high-protein diet and the other half a highcarbohydrate diet. Both diets contained the same number of calories, and both groups of women lost the same amount of weight. But the authors say their recommendations are valid because women with high triglyceride levels - a marker of insulin resistance shed significantly more weight on the highprotein diet. Participants were also more likely to stick with the high-protein diet.

The CSIRO stands by its decision to commercialize the research. "The CSIRO has always published books on its scientific work and put its name to publications, and this is no exception," says a spokeswoman. "The decision to publish was in response to many consumers asking for further details of the diet."

Carina Dennis soldiers buried in Russia suggest that many in Napoleor's army suffered from louse-borne diseases, including typhus and trench fever.

\section{NUMBER CRUNCH}

$\$ 54$ is the cost of a 'custom star kit' through one of the many star-registry agencies that adver tise buying a star in the name of a loved one - a perfect Christmas gift.

1 million people have signed up.

O is the number of privately purchased star names recognized by the International Astronomical Union, the organization in charge of naming celestial objects. 